\title{
Down Under: Shark attack
}

\section{O $p$ het moment gelden ook in Australië forse restricties om de CO- VID-19 besmettingen onder controle te houden, al is het hier zo} dunbevolkt dat het even zoeken is naar iemand die je op een afstand van 1,5 meter kunt houden. Hier kennen we andere gevaren.

Twee jaar geleden ben ik verhuisd naar Queensland. Het Great Barrier Reef zorgt hier voor prachtig onderwaterleven. Op vijf kwartier varen ligt een koraaleilandengroep waartoe ook Heron Island behoort, het eiland waar David Attenborough zijn onderwater natuurfilms heeft gefilmd. Wij gaan meestal met onze boot naar North West Island, waar het wat rustiger is dan op Heron. Maar een paar dagen geleden werden we ineens opgeschrikt door het nieuws dat daar een jonge parkranger is doodgebeten door een haai. Het was zijn droombaan en hij was er net een week mee begonnen. Na een dag hard werken ging de ranger zwemmen om af te koelen. ledereen was al uit het water toen hij ineens gegrepen werd door een haai. Binnen een paar uur is hij overleden.

Een van de parkrangers die erbij was, heeft forse posttraumatische stressklachten en komt bij mij voor behandeling. Als hij de details van het ongeluk beschrijft, merk ik dat ik misselijk word. Ik probeer me te concentreren op zijn verhaal, maar mijn gedachten dwalen af naar onze tripjes met de boot. Hoe vaak heb ik daar niet gezwommen? Ik denk aan de drie meter lange tijgerhaai die de laatste keer onder de boot hing toen ik met mijn slaperige hoofd het water in wilde duiken. We hebben nieuwe harpoenen gekocht en ik kon niet wachten die uit te proberen. Als je een vis speert, verschijnen er meestal binnen enkele seconden één of twee haaien die de vis van je speer proberen te halen. We lachten erom, want haaiaanvallen komen alleen voor in het koudere zuiden, dachten we, niet hier (Ik ben ook een fervent surfer, is dat dan nog wel veilig?).

De ranger praat maar door en ik probeer het risico te relativeren; het is ook niet verstandig om in de schemering te gaan zwemmen, want haaien zien slecht, zeker zonder zonlicht. Maar de golf van paniek komt telkens terug en ik denk alleen maar 'ik wil dit niet horen, ik wil hier weg'. Dan raap ik mezelf bijeen en stop mijn gedachtegang. Deze cliënt heeft mijn hulp nodig. Als hij driekwartier later vertrekt, voelt hij zich wel wat beter gelukkig. Sommige van mijn collega's wilden zich niet meer met kindermishandeling en seksueel misbruik bezighouden nadat ze kinderen hadden gekregen en ik begrijp nu heel goed waarom. Het is verrekte lastig om cliënten te helpen als hun nare ervaringen te dichtbij komen.

\section{ARIANNE STRUIK \\ 'Ik ben directeur van het Institute for Chronically Traumatized Children (ICTC) in Agnes Water (Queensland, Australia), dat gespecialiseerd is in de behandeling van getraumatiseerde kinderen en hun families. Ik ben auteur van het boek Slapende Hon- den? Wakker maken! en als 'flying psych' behandel ik getraumatiseerde kinderen en volwassen in afgelegen gebieden van Australië.'}

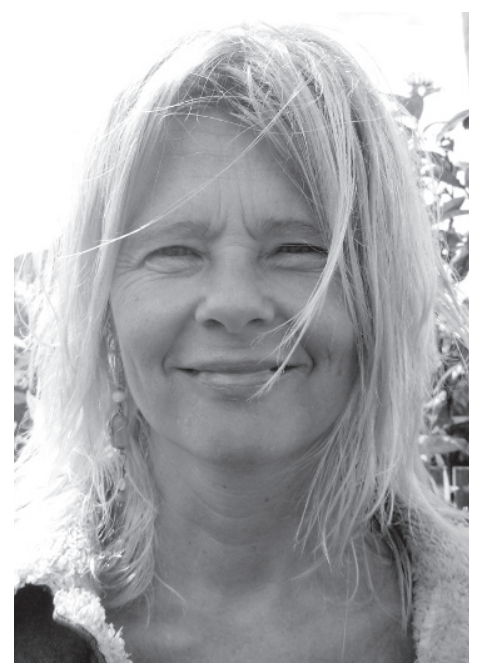

'IK WIL DIT NIET HOREN, IK WIL HIER WEG' 